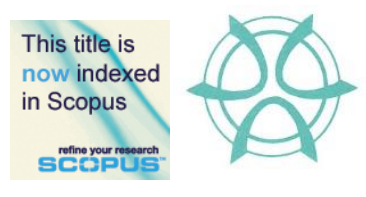

PLANNING MALAYSIA:

Journal of the Malaysian Institute of Planners

VOLUME 17 ISSUE 1 (2019), Page 160 - 175

\title{
BRIDGING THE SUPPLY AND DEMAND GAP FOR AFFORDABLE HOME OWNERSHIP IN MALAYSIA: THE ROLES OF GOVERNMENT AND FINANCIAL INSTITUTIONS
}

\author{
Rosylin Mohd Yusof ${ }^{1}$, Shazida Jan Mohd Khan ${ }^{2}$, Fauziah M. Yusuf ${ }^{3}$, \& \\ Nurul Huda Abdul Majid ${ }^{4}$ \\ ${ }^{1}$ Othman Yeop Abdullah Graduate School of Business \\ ${ }^{2}$ School of Economics, Finance and Banking \\ ${ }^{3}$ Islamic Business School \\ UNIVERSITI UTARA MALAYSIA
}

${ }^{4}$ UNIVERSITI UTARA MALAYSIA KUALA LUMPUR CAMPUS

\begin{abstract}
Promoting homeownership remains a conundrum in a developing economy in Malaysia. Despite significant initiatives pursued by the government, more needs to be done to promote affordable and sustainable homeownership further. Khazanah Report (2018) provides evidence that housing affordability in Malaysia is worsening compared to one reported in 2015.This study therefore aims to empirically assess the role of government in terms of designing policies to promote the supply of affordable homes and the role of financial institutions in terms of providing home financing. The finding reveals that existing housing policies and government programmes have a significant role in promoting homeownership. The finding further suggests that building and completing more units of affordable homes (as captured by housing stocks) and promoting innovative home financing products (both conventional and Islamic) are the most significant variables in promoting homeownership in Malaysia.
\end{abstract}

Keywords: Malaysia, homeownership, government housing effort, affordable homes, home financing 
PLANNING MALAYSIA

Journal of the Malaysia Institute of Planners (2019)

\section{INTRODUCTION}

Promoting affordable homes has always been a daunting task for the government. Coupled with volatilities in the exchange rate, fuel prices and uncertainties in economic fundamental have further challenged the government and other concerned institutions to find appropriate measures and solutions in providing more affordable homes to house the nation.

Despite many efforts taken by the government in the past years, the Malaysian residential housing market is still regarded as unaffordable. A study by Khazanah Research Institute Report (KRI) in 2018 found that the overall Malaysian median-multiple worsens with 5.0 affordability index compared to 4.4 (in 2015) reflecting many Malaysians continue to be locked out of the housing market. In addition, KRI (2015) also reported a mismatch between supply of and demand for affordable homes in Malaysian urban areas which is due to socioeconomic changes, urbanization, and evolving population structures. Bank Negara Malaysia (BNM) reported that in 2017, the supply of affordable homes (RM250,000 or below) is only 20 percent of new Malaysian housing launched in the first quarter of 2017 compared to 33 percent between 2010 to 2014. It is also reported that affordability and mobility elements are causing an increase in demand for housing and at the same time recording an inadequate supply of affordable housing. These challenges further escalate as the house prices continue an increasing trend partly due to the increase in land prices and higher construction costs. To further address the issue of mismatch between demand and supply of affordable houses, the government continues to design policies that will further promote more affordable homes. To this effect, understanding the demand of homeownership affordability and its determinants particularly the government policy variables and institutional variable will shed some light on which particular variables to focus on to promote affordability of homeownership.

Realising the need for a high standard and sustainable housing programme for dynamic socioeconomic development in Malaysia, the $10^{\text {th }}$ Malaysia Economic Plan, and $11^{\text {th }}$ Malaysia Economic Plan were designed. The economic plan acted as a guideline to strategize and to design fitting policies in assuring adequate shelter with quality living environment for the public. The government has worked closely with the financial institutions to provide surety on $100 \%$ financing to potential borrowers. Apart from financial institutions in Malaysia, Employees Provident Fund (EPF), National Mortgage Corporation (CAGAMAS) and several other government agencies also play their roles to impact housing delivery processes. Several housing programmes were also introduced such as My First Home Scheme, Youth Housing Scheme, and MyHome, with the aim to further promote affordable homeownership in Malaysia.

Against this backdrop, this study attempts to investigate whether there exists a significant relationship between the supply factor derived from 
Rosylin Mohd Yusof, Shazida Jan Mohd Khan, Fauziah M. Yusuf, \& Nurul Huda Abdul Majid

Bridging the Supply and Demand Gap for Affordable Home Ownership in Malaysia:The Roles of Government and Financial

Institutions

government's policy (such as housing stocks and land supply) and institutional supply of funds (measured by financing offered by financial institutions) and homeownership in Malaysia. A significant relationship between the government policy variables (measured by supply factor derived from the government policies) and institutional supply factor (measured by amount of financing offered) suggests that government policies and financial institutions can play effective roles to promote home affordability in Malaysia.

\section{LITERATURE REVIEW}

Housing plays an important role in enhancing the wellbeing of the society in terms of contributing to the physical and mental health, education, employment and security outcomes; a failure to achieve that will lead to housing stress (Baqutaya, Ariffin, \& Raji, 2016). Existing literature describes housing as a social policy tool (Rowley \& Ong, 2012) and suggest how policy tool should be able to contribute towards shelter and non-shelter outcomes such as health, crime, employment and education (Phibbs \& Young, 2005). Therefore, designing public policy has become increasingly crucial as it demands provision of public housing, updating new policy development as well as guiding directions for future policies. As for Malaysia, housing policies have been adopting a pragmatic and inclusive role of the government by providing institutional support for a well functional housing delivery (Abdullahi et al., 2011).

For the past few years, Malaysia has experienced increasing demand for affordable homes especially from the middle income group (MIG) and low income group (LIG). This trend is consistent with the growing concern that LIG and the poor are being at disadvantaged as a result of the implementation of housing policy in developing countries (Abdullahi et al., 2011). The Malaysian government has introduced many new policies where developers and the government work together, responsive to the demands imposed upon the industry, concertedly to further promote supply of more affordable homes. Policy and regulatory changes by the government must be embraced because intervention by government in the competitive housing development industry is essential. Baqutaya et al. (2016) and Osman, Yusop, Shuid and Abdullah (2017) suggest that house price, home financing and housing schemes' policy are determinants that significantly affect affordability in property owning and enhancement of the living quality in Malaysia. Therefore, to promote affordable homeownership requires a great deal of policy attention in order to enhance homeownership for a better wellbeing and quality living.

The choice of banks also influences the chances of getting house financing. Amin (2008) studies the choice criteria for Islamic home financing in Labuan, Malaysia. His finding suggests that with Islamic home financing, borrowers pay lower monthly instalments, greater transparency in practices and 100 percent financing which fulfils the first five criteria that influence the 
PLANNING MALAYSIA

Journal of the Malaysia Institute of Planners (2019)

decision of a house buyer. Similarly, Hamid and Masood (2011) assert that customers in Pakistan choose efficient services, price, bank reputation and product flexibility as among the important factors considered in choosing Islamic mortgages. For the Islamic home financing in Malaysia, the institutions have established innovative products to support the government's efforts to promote homeownership further. Thirteen (13) out of 23 products offered by Islamic banks are based on the shariah principles of Murabahah, which includes Bai Bithaman Ajil and Tawarruq, and six out of the total products are based on Mushrakah Mutanaqisah. Meanwhile, the less popular contracts are Ijarah and Istisna'a (BNM, 2016)

\section{RESEARCH METHODOLOGY}

To assess the roles of government's efforts and Islamic financial institutions in promoting home affordability in Malaysia, we adopt variance decompositions (VDC) and impulse response functions (IRF) to empirically explore the impact of shocks in each selected independent variable on homeownership.

Figure 1 illustrates the research framework where the dependent variable of homeownership is measured by the number of homeownership transferred to Malaysian citizens. Whereas, the independent variables include government efforts, represented by the existing residential stocks unit and land supply for building development, and both Islamic home financing and conventional home financing represented by total Islamic home financing approved for real estate sector. House price index (HPI) and gross domestic products (GDP) are the control variables. The summary of the measurement of the variables is illustrated in Table 1.

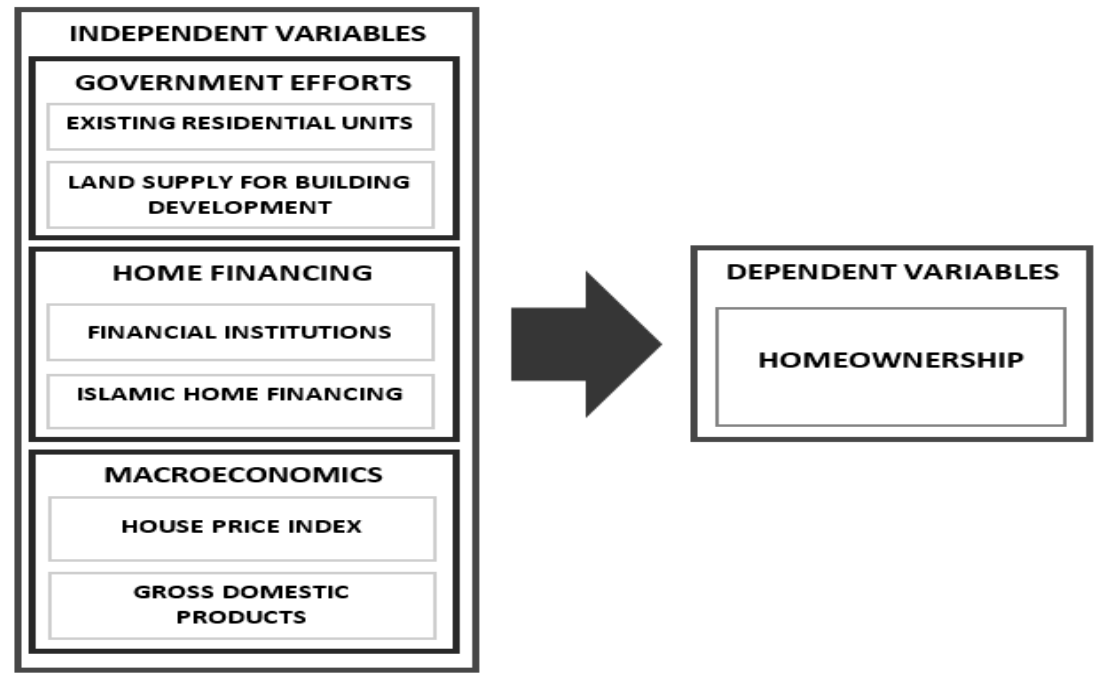

Figure 1: Research framework 
Rosylin Mohd Yusof, Shazida Jan Mohd Khan, Fauziah M. Yusuf, \& Nurul Huda Abdul Majid

Bridging the Supply and Demand Gap for Affordable Home Ownership in Malaysia:The Roles of Government and Financial Institutions

Table 1: Measurement of variables

\begin{tabular}{|c|c|c|c|}
\hline Variables & Measurement & Period & Sources \\
\hline Homeownership & $\begin{array}{l}\text { Number of homeownership } \\
\text { transferred }\end{array}$ & \multirow{7}{*}{$\begin{array}{l}\text { Quarter } \\
\text { One } 2008 \\
\text { to Quarter } \\
\text { Four } 2015\end{array}$} & \multirow{3}{*}{$\begin{array}{c}\text { National Property } \\
\text { Information Centre } \\
\text { (NAPIC) }\end{array}$} \\
\hline $\begin{array}{c}\text { Existing } \\
\text { Residential Stock }\end{array}$ & $\begin{array}{c}\text { Number of launched and built } \\
\text { units }\end{array}$ & & \\
\hline Land Supply & $\begin{array}{l}\text { Hectares of land approved for } \\
\text { building }\end{array}$ & & \\
\hline $\begin{array}{l}\text { Housing Price } \\
\text { Index }\end{array}$ & $\begin{array}{c}\text { Malaysia house price index (base } \\
\text { year 2010) }\end{array}$ & & $\begin{array}{l}\text { Dept. of Statistics } \\
\text { Malaysia (DOSM) }\end{array}$ \\
\hline $\begin{array}{l}\text { Gross Domestic } \\
\text { Products }\end{array}$ & Malaysian GDP (base year 2010) & & $\begin{array}{l}\text { Economic Planning } \\
\text { Unit (EPU) }\end{array}$ \\
\hline $\begin{array}{c}\text { Financial } \\
\text { Institutions }\end{array}$ & $\begin{array}{l}\text { Total home financing approved for } \\
\text { real estate by all banks in Malaysia }\end{array}$ & & \multirow{2}{*}{$\begin{array}{c}\text { Bank Negara } \\
\text { Malaysia (BNM) }\end{array}$} \\
\hline Islamic Funding & $\begin{array}{l}\text { Home financing approved for real } \\
\text { estate by Malaysia Islamic banks }\end{array}$ & & \\
\hline
\end{tabular}

Increasing demand for affordable homes could cause additional years to elapse before the required supply is available due to shortages in supply of construction materials or waiting for improved components (Costello, 2014; Gu, Michael, \& Cheng, 2015). The supply of housing stocks will always deviate from equilibrium and once the supply is not at the right place and at the right time, the housing planning policy may disrupt the balance between supply and demand in the housing market (Baer \& Kauw, 2016). Yet, real estate boom is still a reason that is affecting people's decision to own a house and oversupply or shortages of properties is a separate issue (Phang \& Helble, 2016). Apart from demand and supply, preference to newly launched and built units (in particular, existing residential stock units) is expected to react positively and significantly with homeownership (Poon \& Garrat, 2012).

Land markets exert an outstanding influence over the different socioeconomic strata to homeownership on urban land with varying quality (Baer \& Kauw, 2016) and at the same time hindered by land use policy (Ayoade \& Ahmed, 2014) as housing supply is affected by land supply (Gu et al., 2015). Locations with the best facilities and green environment offer more dynamic environment compared to those that lack a minimum of urban-environmental standards (Lee, 2009; Zainal, Kaur, Ahmad, \& Khalili, 2012; Malik \& Wahid, 2014). The significant relationship between land price, the dynamics of land supply, land tenure and the allocation of land (i.e. land market), determine the influence on urban structuring and the general functioning of a city (Kasanga, 1995; Hui, 2004; Adam, 2015; Irumba, 2015). We therefore postulate that there is a significant positive relationship between total land supply and 
PLANNING MALAYSIA

Journal of the Malaysia Institute of Planners (2019)

homeownership. In this study, the role of financial institutions is measured by the total amount approved for home financing and is expected to have a positive relationship with homeownership (Barakova, Bostic, Calem, \& Wachter, 2003).

The mortgage rate is the most important factor which significantly influences the decision to own a home (Claussen, 2013; Ismail, Bujang, Jiram, Zarin, \& Jaafar, 2015; Kajuth, Knetsch, \& Pinkwart, 2016). Avoiding interestrate as a benchmark for product pricing (Mohammad \& Gauri, 2015), simple favourable regulatory and tax changes for homeowners offered by the government, and support for more banks to offer Islamic home financing products (Smolo \& Hassan, 2011) have managed to attract more individuals to purchase a home.

Meanwhile, the attractive regulations on the home purchase plan and varieties of Islamic banking products could increase customers' confidence in Islamic mortgage products compared to the conventional products (Meera \& Abdul-Razak, 2005; Tameme \& Asutay, 2012; Usman \& Lizam, 2016). The government could play a more effective role in increasing homeownership rates by raising the awareness of innovative and alternative Islamic home financing among the Muslim community (Ibhler \& Lucius, 2003; Oyewole, 2010; Smolo \& Hassan, 2011).

Increase in house prices can directly push the demand for homeownership downwards since a greater amount of capital borrowing will be required to acquire affordable homes (Phang, 2010) and small changes in liquidity fully impact house prices in one direction (Taltavull \& White, 2016). In addition, the sentiment to wait and see for a reduced price in future (Shiller, 2007; Lee, 2009) and the low nett worth buyers will have less creditworthiness to obtain higher financing from banks and expect low interest rates packages (Kajuth et al., 2016). Interest rate is regarded as the cost of borrowing and in this present study it is expected that it will be negatively related to homeownership.

In the same vein, Udechukwu (2008) and Claussen (2013) state that an increase in household disposable income is a significant factor behind economic empowerment which influences homeownership decision positively. Ageing population (Phang \& Helble, 2016) with high unemployment rates (Kagochi \& Mace, 2009) would rather avoid homeownership and rely more on their internal sources, to finance their normal consumption and investment needs.

The model of this study incorporates existing residential stock units and land supply into the analysis in order to evaluate the government efforts in promoting homeownership. In order to evaluate Islamic and conventional home financing in promoting ownership, the data on Islamic home financing approved and conventional home financing approved are utilised. However, consistent with Kassim, Majid and Yusof (2009), this study does not incorporate all the variables in a single model so that we can make a meaningful comparison between the effects of government efforts, financial institutions and Islamic home financing 
Rosylin Mohd Yusof, Shazida Jan Mohd Khan, Fauziah M. Yusuf, \& Nurul Huda Abdul Majid

Bridging the Supply and Demand Gap for Affordable Home Ownership in Malaysia:The Roles of Government and Financial

Institutions

on homeownership. Table 2 summarizes the time series analysis techniques used in this study in corresponding to the research objectives.

Table 2: Research objectives and time series analysis techniques

\begin{tabular}{ll}
\hline \multicolumn{1}{c}{ Research Objective } & $\begin{array}{c}\text { Time Series Analysis } \\
\text { Techniques }\end{array}$ \\
\hline $\begin{array}{l}\text { 1. To examine whether there is a long-run relationship } \\
\text { between the level of homeownership of Malaysian } \\
\text { citizens and government efforts, total financing and }\end{array}$ & $\begin{array}{l}\text { Johansen Co-integration } \\
\text { Approach (Long-run } \\
\text { analysis) }\end{array}$ \\
Islamic home financing. & $\begin{array}{l}\text { Impulse Response } \\
\text { 2. To identify whether there is significant impact of } \\
\text { changes in government efforts, total financing and } \\
\begin{array}{l}\text { Islamic home financing on homeownership in the } \\
\text { short-run. }\end{array}\end{array}$ \\
\hline $\begin{array}{l}\text { run) and Forecast Error of } \\
\text { Variance Decomposition } \\
\text { (FEVD) }\end{array}$
\end{tabular}

The equation for Least Squares at First Difference model used in this study is expressed in the Appendix 1.

\section{RESEARCH FINDINGS AND ANALYSIS}

We start our analysis by presenting the descriptive statistics of common sample for homeownership in Malaysia for 2008-2015. In Table 3, all variables show small standard deviation except for Islamic home financing variable which shows the highest deviation at 0.71 . The set of data further reveals peaked positive value of kurtosis which means the value of the kurtosis are mostly reflecting normal distribution with values more than 0 but less than 3 . Only Islamic and total home financing exceeds slightly more than 3.0. Generally these results indicate that the data is normally distributed.

Table 3: Descriptive state of common sample

\begin{tabular}{|c|c|c|c|c|c|c|c|}
\hline & $\operatorname{lnHOT}$ & $\operatorname{lnESU}$ & $\operatorname{lnLSS}$ & HPI & $\operatorname{lnGDP}$ & $\operatorname{lnHFI}$ & $\operatorname{lnHFT}$ \\
\hline Mean & 11.000 & 10.143 & 8.213 & 5.118 & 8.935 & 8.356 & 10.022 \\
\hline Median & 11.004 & 10.050 & 8.220 & 5.102 & 8.927 & 8.632 & 10.077 \\
\hline Maximum & 11.208 & 10.940 & 8.685 & 5.440 & 9.101 & 9.112 & 10.404 \\
\hline Minimum & 10.744 & 9.468 & 7.479 & 4.857 & 8.757 & 6.628 & 9.365 \\
\hline Std. Dev. & 0.111 & 0.411 & 0.391 & 0.203 & 0.085 & 0.707 & 0.278 \\
\hline Skewness & -0.217 & 0.412 & -0.443 & 0.143 & 0.068 & -1.094 & -0.739 \\
\hline Kurtosis & 2.840 & 2.322 & 2.258 & 1.555 & 2.302 & 3.228 & 3.135 \\
\hline Jarque-Bera & 0.286 & 1.519 & 1.781 & 2.894 & 0.675 & 6.452 & 2.934 \\
\hline Probability & 0.867 & 0.468 & 0.410 & 0.235 & 0.714 & 0.040 & 0.231 \\
\hline
\end{tabular}


PLANNING MALAYSIA

Journal of the Malaysia Institute of Planners (2019)

\begin{tabular}{lrrrrrrr}
\hline Sum & 351.999 & 324.581 & 262.811 & 163.786 & 285.915 & 267.408 & 320.708 \\
\hline Sum Sq. Dev. & 0.382 & 5.235 & 4.736 & 1.274 & 0.222 & 15.497 & 2.388 \\
\hline Observations & 32 & 32 & 32 & 32 & 32 & 32 & 32 \\
\hline
\end{tabular}

Table 4 presents correlation analysis results for the sample period. The results indicate a high correlation between GDP and House Price Index. This result concurs with existing studies conducted on Asian Housing Market that shows a strong positive correlation between GDP and HPI (Piazzesi \& Schneider, 2009; Zhu, 2006). There exists a strong positive correlation between HPI and HFI which indicates that Islamic home financing are generally asset based and thus more linked to price of the asset compared to the financing of the conventional banks.

Table 4: Summary of data correlation analysis

\begin{tabular}{lccccccc}
\hline Correlation & $\ln H O T$ & $\operatorname{lnESU}$ & $\operatorname{lnLSS}$ & HPI & $\operatorname{lnGDP}$ & $\operatorname{lnHFI}$ & $\ln H F T$ \\
\hline $\ln$ ESU & -0.453 & 1.000 & & & & & \\
\hline $\ln \mathrm{SS}$ & -0.039 & 0.378 & 1.000 & & & & \\
HPI & 0.380 & -0.294 & -0.417 & 1.000 & & & \\
lnGDP & 0.489 & -0.448 & -0.312 & 0.930 & 1.000 & & \\
\hline $\ln \mathrm{nFI}$ & 0.549 & -0.443 & -0.445 & 0.829 & 0.768 & 1.00 & \\
\hline $\ln \mathrm{HFT}$ & 0.616 & -0.467 & -0.249 & 0.7740 & 0.783 & 0.8827 & 1.000 \\
\hline
\end{tabular}

Table 5 further provides evidence that at $10 \%$ significance level, the ADF unit root test for all variables (HOT, ESU, LSS, HPI, GDP, HFT and HFI) are all stationary at first differenced I(1). These results enable us to proceed with the cointegration test.

Table 5: Summary of augmented Dickey-Fuller unit root tests

\begin{tabular}{|c|c|c|c|c|c|}
\hline \multirow[b]{2}{*}{ Variables } & \multicolumn{2}{|c|}{ At Level } & \multicolumn{2}{|c|}{ At 1st Difference } & \multirow[b]{2}{*}{$\begin{array}{c}\text { Results at } \\
10 \%\end{array}$} \\
\hline & Intercept & $\begin{array}{l}\text { Trend and } \\
\text { Intercept }\end{array}$ & Intercept & $\begin{array}{l}\text { Trend and } \\
\text { Intercept }\end{array}$ & \\
\hline Homeownership & $-2.749 *$ & -2.725 & $-7.291 * * *$ & $-4.838 * * *$ & $\mathrm{I}(1)$ \\
\hline $\begin{array}{l}\text { Residential } \\
\text { Stocks }\end{array}$ & $-2.672 *$ & -2.765 & $-7.070 * * *$ & $-6.871 * * *$ & $\mathrm{I}(1)$ \\
\hline Land Supply & $-4.597 * * *$ & $-6.413 * * *$ & $-8.319 * * *$ & $-7.936 * * *$ & $\mathrm{I}(1)$ \\
\hline $\begin{array}{l}\text { House Price } \\
\text { Index }\end{array}$ & $2.214 * i$ & $-3.852 * * i$ & $-4.161 * * * i$ & $-4.935 * * * i$ & $\mathrm{I}(1)$ \\
\hline $\begin{array}{l}\text { Gross Domestic } \\
\text { Products }\end{array}$ & 0.258 & $-5.593 * * *$ & $-5.006 * * *$ & $-4.728 * * *$ & $\mathrm{I}(1)$ \\
\hline $\begin{array}{l}\text { Islamic Home } \\
\text { Financing }\end{array}$ & $-4.262 * * *$ & -1.221 & -0.790 & $-5.851 * * *$ & $\mathrm{I}(1)$ \\
\hline $\begin{array}{l}\text { Conventional } \\
\text { Home Financing }\end{array}$ & $-3.635 * * *$ & -2.120 & -2.035 & $-9.090 * * * i$ & $\mathrm{I}(1)$ \\
\hline Null Hypothesis e & t: There is & root. & & & \\
\hline
\end{tabular}


Rosylin Mohd Yusof, Shazida Jan Mohd Khan, Fauziah M. Yusuf, \& Nurul Huda Abdul Majid

Bridging the Supply and Demand Gap for Affordable Home Ownership in Malaysia:The Roles of Government and Financial

Institutions

*** - at 1 percent significance level

** $\quad$ - at 5 percent significance level

* $\quad$ - at 10 percent significance level

$i \quad$ - Based on Phillips and Perron (PP) test

To unravel the long run dynamics between home ownership and the explanatory variables such as government efforts, financial institutions and Islamic home financing, we proceed with Augmented Dickey Fuller and Johansen Cointegration tests. Table 6 and Table 7 present the cointegration test results based on the two afore mentioned tests respectively.

Table 6: Augmented Dickey-Fuller tests

\begin{tabular}{llc}
\hline Endogenous variable & Exogenous variable & $\begin{array}{c}\text { Augmented Dickey-Fuller } \\
\text { test }\end{array}$ \\
\hline $\begin{array}{l}\text { Homeownership } \\
(\text { LgHOT) }\end{array}$ & Housing Supply (LgESU) & $-6.872 * * *$ \\
\hline $\begin{array}{l}\text { Homeownership } \\
(\text { LgHOT })\end{array}$ & Land Supply (LgLSS) & $-7.936 * * *$ \\
$\begin{array}{l}\text { Homeownership } \\
(\text { LgHOT) }\end{array}$ & Housing Price (LgHPI) & $-4.935 * * * i$ \\
$\begin{array}{l}\text { Homeownership } \\
(\text { LgHOT })\end{array}$ & Household Income (LgGDP) & $-4.728 * * *$ \\
$\begin{array}{l}\text { Homeownership } \\
(\text { LgHOT) }\end{array}$ & Islamic Financing (LgHFI) & $-5.851 * * *$ \\
\hline $\begin{array}{l}\text { Homeownership } \\
(\text { LgHOT })\end{array}$ & $\begin{array}{l}\text { Conventional Financing } \\
\text { (LgHFC) }\end{array}$ & $-9.090709 * * * i$ \\
\hline Note: $* * * p<0.01$ & & \\
\hline
\end{tabular}

Table 7: Johansen cointegration results

\begin{tabular}{|c|c|c|c|c|c|c|}
\hline Series & $\operatorname{lnESU}$ & $\operatorname{lnLSS}$ & HPI & $\operatorname{lnGDP}$ & $\ln \mathrm{HFI}$ & $\ln \mathrm{HFC}$ \\
\hline $\begin{array}{l}\ln \mathrm{HOT} \\
\operatorname{lnESU} \\
\operatorname{lnLSS} \mathrm{HPI} \\
\operatorname{lnGDP}\end{array}$ & $\begin{array}{l}0.242460 \\
(0.21194)\end{array}$ & $\begin{array}{l}0.025971 \\
(0.16492)\end{array}$ & $\begin{array}{l}0.028671 \\
(0.00572)\end{array}$ & $\begin{array}{c}- \\
13.49778 \\
(2.36795)\end{array}$ & & \\
\hline $\begin{array}{l}\ln \mathrm{HOT} \\
\ln \mathrm{ESU} \\
\operatorname{lnLSS} \mathrm{HPI} \\
\operatorname{lnGDP} \\
\operatorname{lnHFI}\end{array}$ & $\begin{array}{c}- \\
0.148589 \\
(0.06687)\end{array}$ & $\begin{array}{l}0.010702 \\
(0.04502)\end{array}$ & $\begin{array}{l}0.020625 \\
(0.00221)\end{array}$ & $\begin{array}{c}- \\
8.850561 \\
(0.89587)\end{array}$ & $\begin{array}{c}- \\
0.192125 \\
(0.03906)\end{array}$ & \\
\hline $\begin{array}{l}\ln \mathrm{HOT} \\
\operatorname{lnESU} \\
\operatorname{lnLSS} \text { HPI } \\
\operatorname{lnGDP} \\
\operatorname{lnHFC}\end{array}$ & $\begin{array}{l}0.104447 \\
(0.10288)\end{array}$ & $\begin{array}{c}- \\
0.163381 \\
(0.07464)\end{array}$ & $\begin{array}{c}- \\
0.008661 \\
(0.00290)\end{array}$ & $\begin{array}{l}4.953256 \\
(1.29749)\end{array}$ & & $\begin{array}{l}0.248419 \\
(0.17539)\end{array}$ \\
\hline
\end{tabular}


PLANNING MALAYSIA

Journal of the Malaysia Institute of Planners (2019)

Tables 8, 9 and 10 further indicate that there exists a significant long run relationship between government efforts, financial institutions and Islamic home financing and home ownership in Malaysia. These results lend support to studies across countries on the effects of land supply and housing stocks on homeownership in Hong Kong and China (Lee, 2009; Hui, 2004), Ethiopia (Adam, 2015); UK, Australia, Ukraine (Ayoade \& Ahmad, 2014; Costello, 2014; Kryvobokov, 2004). Furthermore, our findings that there exists a long run relationship between financial institutions and homeownership concur with the results of Garriga, Gavin and Schalgenhauf (2006), which also allude that innovations in financial markets, access to mortgage finance and reducing payment constraints can allow consumers to purchase homes. The results on Islamic home financing affecting the homeownership in Malaysia also augurs well with the study of Usman and Lizam (2016) for Nigeria, which reveal that religious perception controls the buyers intention of using mortgage in financing homeownership. At this juncture, we can also conclude that concerted efforts among government, financial institutions and Islamic home financing can further promote homeownership in Malaysia.

Table 8: Hypotheses and findings

\begin{tabular}{llc}
\hline Variables & \multicolumn{1}{c}{ Hypotheses } & Long-run Analysis \\
\hline $\begin{array}{l}\text { Homeownership and } \\
\text { Existing Residential }\end{array}$ & $\begin{array}{l}\text { H1: There is a relationship between } \\
\text { number of existing stocks and }\end{array}$ & Accept H1 \\
$\begin{array}{l}\text { Homeownership } \\
\text { Homeownership and }\end{array}$ & $\begin{array}{l}\text { H2: There is a relationship between } \\
\text { total land supply and Homeownership }\end{array}$ & Accept H2 \\
\hline
\end{tabular}

Table 9: Hypotheses and findings of the study - financial institutions

\begin{tabular}{llc}
\hline Variables & Hypotheses & Long-run Analysis \\
Homeownership and & H3: There is a relationship between & Accept H3 \\
Islamic Home Financing & total financing and Homeownership. & \\
\hline
\end{tabular}

Table 10: Hypotheses and findings of the study - Islamic home financing

\begin{tabular}{llc}
\hline Variables & Hypotheses & Long-run Analysis \\
\hline $\begin{array}{l}\text { Homeownership and } \\
\text { Islamic Financing }\end{array}$ & H4: There is a relationship between & Accept H4 \\
& Islamic home financing and & \\
\hline
\end{tabular}

Meanwhile, as highlighted in Tables 11 and 12, similarly for Islamic Home Financing (HFI), shocks in homeownership that is attributable to shocks in HFI accounts for about 4-5 percent and this also represents a significant amount compared to the other variables. We can thus conclude that for financial institutions and Islamic home financing also promote homeownership in both short run and long run. These findings lend support that government policies 
Rosylin Mohd Yusof, Shazida Jan Mohd Khan, Fauziah M. Yusuf, \& Nurul Huda Abdul Majid Bridging the Supply and Demand Gap for Affordable Home Ownership in Malaysia:The Roles of Government and Financial Institutions

effecting land supply and housing supply coupled with increased financing to real estate sector by financial institutions (both total financing and financing offered by Islamic banks) can further promote home ownership in Malaysia.

Table 11: Variance decomposition of homeownership

\begin{tabular}{cccccccc}
\hline Period & S.E. & DHOT & DGDP & DHFI & DHPI & DESU & DLSS \\
\hline 1 & 0.105 & 100.00 & 0.000 & 0.000 & 0.000 & 0.000 & 0.000 \\
\hline 2 & 0.115 & 94.642 & 2.522 & 0.204 & 0.122 & 0.029 & 2.477 \\
\hline 3 & 0.118 & 89.526 & 2.530 & 1.837 & 3.229 & 0.519 & 2.355 \\
\hline 4 & 0.120 & 86.933 & 2.553 & 2.044 & 4.788 & 1.026 & 2.653 \\
\hline 5 & 0.121 & 86.431 & 3.035 & 2.017 & 4.756 & 1.142 & 2.616 \\
\hline 6 & 0.121 & 86.041 & 3.060 & 2.290 & 4.764 & 1.172 & 2.670 \\
\hline 7 & 0.122 & 85.821 & 3.101 & 2.331 & 4.809 & 1.187 & 2.749 \\
\hline 8 & 0.122 & 85.77 & 3.128 & 2.329 & 4.810 & 1.190 & 2.768 \\
\hline 9 & 0.122 & 85.665 & 3.190 & 2.376 & 4.7992 & 1.192 & 2.775 \\
\hline 10 & 0.122 & 85.613 & 3.188 & 2.414 & 4.811 & 1.197 & 2.774 \\
\hline \multicolumn{7}{c}{ Cholesky Ordering no 1: DHOT DGDP DHFI DHPI DESU DLSS } \\
\hline \multicolumn{7}{c}{}
\end{tabular}

Table 12: Variance decomposition of homeownership

\begin{tabular}{ccrrrrrr}
\hline Period & \multicolumn{1}{l}{ S.E. } & \multicolumn{1}{c}{ DHOT } & \multicolumn{1}{c}{ DGDP } & \multicolumn{1}{c}{ DHPI } & \multicolumn{1}{c}{ DHFI } & \multicolumn{1}{c}{ DESU } & DLSS \\
\hline 1 & 0.105 & 100.00 & 0.000 & 0.000 & 0.000 & 0.000 & 0.000 \\
\hline 2 & 0.115 & 94.642 & 2.522 & 0.0196 & 0.307 & 0.0297 & 2.477 \\
\hline 3 & 0.118 & 89.526 & 2.530 & 1.241 & 3.825 & 0.519 & 2.355 \\
\hline 4 & 0.120 & 86.933 & 2.553 & 3.119 & 3.713 & 1.026 & 2.653 \\
\hline 5 & 0.123 & 86.431 & 3.035 & 3.098 & 3.675 & 1.142 & 2.616 \\
\hline 6 & 0.121 & 86.041 & 3.060 & 3.087 & 3.967 & 1.172 & 2.670 \\
\hline 7 & 0.122 & 85.821 & 3.101 & 3.097 & 4.043 & 1.187 & 2.749 \\
\hline 8 & 0.122 & 85.77 & 3.128 & 3.107 & 4.032 & 1.190 & 2.768 \\
\hline 9 & 0.122 & 85.66 & 3.190 & 3.106 & 4.068 & 1.1924 & 2.775 \\
\hline 10 & 0.122 & 85.613 & 3.188 & 3.105 & 4.119 & 1.197 & 2.774 \\
\hline \multicolumn{7}{c}{ Cholesky Ordering no 2: DHOT DGDP DHPI DHFI DESU DLSS } & \\
\hline
\end{tabular}

We further extend our analysis by examining the effects of a shock in the dependent variable that is attributable to shocks in the explanatory variables i.e. government efforts, financial institutions and Islamic home financing in the short run. Based on Tables 13 and 14, With HFT (Total Financing Model which comprises financing offered by both Conventional and Islamic banks) model, in the short run, GDP and HFT account for around 8 percent and 7 to 10 percent of forecast error variance of Homeownership respectively for both orderings. This result suggests that financial institutions play a more significant role in promoting 
home ownership in the short run. This result augurs well with the results of existing studies like Painter and Redfearn (2002), Garriga et al. (2006), Claussen (2013) and Ismail et al. (2015), which assert the importance offered by financial institutions to promote home ownership.

Table 13: Variance decomposition of homeownership

\begin{tabular}{cccccccc}
\hline Period & S.E. & DHOT & DGDP & DHFT & DHPI & DESU & DLSS \\
\hline 1 & 0.098 & 100.000 & 0.000 & 0.000 & 0.000 & 0.000 & 0.000 \\
\hline 2 & 0.107 & 93.986 & 4.999 & 0.131 & 0.012 & 0.231 & 0.642 \\
\hline 3 & 0.113 & 85.529 & 4.708 & 8.586 & 0.188 & 0.219 & 0.770 \\
\hline 4 & 0.115 & 83.347 & 4.667 & 9.275 & 0.311 & 1.651 & 0.748 \\
\hline 5 & 0.118 & 79.724 & 6.445 & 10.197 & 0.928 & 1.675 & 1.031 \\
\hline 6 & 0.119 & 77.973 & 7.436 & 10.065 & 1.236 & 2.123 & 1.168 \\
\hline 7 & 0.120 & 77.254 & 7.453 & 10.019 & 1.456 & 2.280 & 1.537 \\
\hline 8 & 0.121 & 77.216 & 7.365 & 10.060 & 1.439 & 2.293 & 1.626 \\
\hline 9 & 0.122 & 76.121 & 8.079 & 10.115 & 1.534 & 2.503 & 1.648 \\
\hline 10 & 0.122 & 75.702 & 8.422 & 10.070 & 1.558 & 2.581 & 1.667 \\
\hline \multicolumn{7}{c}{ Cholesky } & Ordering no 1: DHOT DGDP DHFT DHPI DESU DLSS \\
\hline
\end{tabular}

Table 14: Variance decomposition of homeownership

\begin{tabular}{clllllll}
\hline Period & S.E. & DHOT & DGDP & DHFT & DHPI & DESU & DLSS \\
\hline 1 & 0.098 & 100.000 & 0.000 & 0.000 & 0.000 & 0.000 & 0.000 \\
\hline 2 & 0.107 & 93.986 & 4.999 & 0.002 & 0.141 & 0.231 & 0.642 \\
3 & 0.113 & 85.529 & 4.708 & 2.313 & 6.461 & 0.219 & 0.770 \\
\hline 4 & 0.115 & 83.347 & 4.667 & 2.751 & 6.835 & 1.651 & 0.748 \\
\hline 5 & 0.118 & 79.724 & 6.445 & 4.025 & 7.100 & 1.675 & 1.031 \\
\hline 6 & 0.119 & 77.973 & 7.436 & 4.392 & 6.909 & 2.123 & 1.168 \\
\hline 7 & 0.120 & 77.254 & 7.453 & 4.478 & 6.997 & 2.280 & 1.537 \\
\hline 8 & 0.121 & 77.216 & 7.365 & 4.467 & 7.032 & 2.293 & 1.626 \\
\hline 9 & 0.122 & 76.121 & 8.079 & 4.647 & 7.002 & 2.503 & 1.648 \\
\hline 10 & 0.122 & 75.702 & 8.422 & 4.636 & 6.992 & 2.581 & 1.667 \\
\hline \multicolumn{7}{c}{ Cholesky Ordering no 1: DHOT DGDP DHFT DHPI DESU DLSS } \\
\hline
\end{tabular}

\section{CONCLUSION}

This paper highlights the role of government efforts through policy intervention for land supply and policies on existing supply stocks to promote homeownership in Malaysia. Given the importance of owning a home which extends beyond 'having a roof over the head' as it also affects the wellbeing of the family members with repercussions on societal and economic factors, the study seeks to investigate whether the government's efforts in bridging the demand and supply 
Rosylin Mohd Yusof, Shazida Jan Mohd Khan, Fauziah M. Yusuf, \& Nurul Huda Abdul Majid

Bridging the Supply and Demand Gap for Affordable Home Ownership in Malaysia:The Roles of Government and Financial

Institutions

gap to promote homeownership is to a certain extent successful. The findings of this study provide evidence that government efforts, financial institutions and macroeconomic fundamentals all play significant roles in promoting homeownership in Malaysia. Thus, concerted efforts among industry players and policymakers and the macroeconomic indicators must be maintained to promote homeownership further. Our short-run dynamics on the other hand, suggest that income as measured by GDP and total financing by Financial Institutions and Islamic Home Financing are three significant variables that affect homeownership in the short run. These results further confirm the existing theories on homeownership affordability which identify income and financing from financial institutions are the two most significant factors to promote homeownership in Malaysia. Policy ramifications for the government of Malaysia to promote homeownership affordability should therefore focus on increasing income and supporting financial institutions to provide financing can further promote homeownership in Malaysia.

The results of this study also hope to benefit the home buyers to be better informed on the government initiatives and the role of financial institutions. Homebuyers will also have a better understanding before making a decision to buy a house. For the financial institutions, understanding the impact of home financing will enable them to design innovative and promotional packages for the home buyers. For the government and policymakers, understanding the measures undertaken thus far and their role in bridging the gap between the supply and demand will enable them to review existing and design future policies to promote homeownership in Malaysia further.

\section{ACKNOWLEDGEMENT}

The authors wish to express sincere appreciation to the Ministry of Higher Education (MoHE) for funding this study under the Transdisciplinary Research Grant Scheme (TRGS) (SO Code: 13166).

\section{REFERENCES}

Abdullahi, B. C., Wan, N. A., Abdullah, A. A., Beksin, A. M., Alashwal, A. M., \& Deraman, R. (2011). Sustainable housing policy and low-income group housing: the Malaysian Experience. Australian Journal of Basic and Applied Sciences, 5(6), 170-180.

Adam, A. G. (2015). Land readjustment as an alternative land development tool for periurban areas of Ethiopia. Property Management, 33(1), 36-58.

Amin, H. (2008). Choice criteria for Islamic home financing: Empirical investigation among Malaysian bank customers. International Journal of Housing Markets and Analysis, 1(3), 256-274.

Ayoade, O., \& Ahmed, V. (2014). An assessment of land use sources of barriers and the community-based housing model in the UK. International Journal of Housing Markets and Analysis, 7(4), 539-558. 
PLANNING MALAYSIA

Journal of the Malaysia Institute of Planners (2019)

Bank Negara Malaysia, B. N. M. (2016). Annual Report 2009. Retrieved from http://www.bnm.gov.my/files/publication/ar/bm/2016/ar2016_buku.pdf

Barakova, I., Bostic, R. W., Calem, P. S., \& Wachter, S. M. (2003). Does credit quality matter for homeownership? University of Penn Law \& Econ Research Paper 0340.

Baqutaya, S. A., Ariffin, S., \& Raji, F. (2016). Affordable housing policy: Issues and challenges among middle-income groups. International Journal of Social Science and Humanity, 6(6), 433-436.

Baer, L., \& Kauw, M. (2016). Behavior of land markets and restrictions on housing access in Buenos Aires between 2003 and 2013. International Journal of Housing Markets and Analysis, 9(4), 538-553.

Claussen, C. A. (2013). Are Swedish houses overpriced? International Journal of Housing Markets and Analysis, 6(2), 180-196

Costello, G. (2014). Land price dynamics in a large Australian urban housing market. International Journal of Housing Markets and Analysis, 7(1), 42-60.

Garriga, C., Gavin, W. T., \& Schlagenhauf, D. (2006). Recent trends in homeownership. Federal Reserve Bank of St. Louis Review, 88(5), 397-411.

Gu, G., Michael, L., \& Cheng, Y. (2015). Housing supply and its relationships with land supply. International Journal of Housing Markets and Analysis, 8(3), 375-395.

Hamid, A., \& Masood, O. (2011). Selection criteria for Islamic home financing: A case study of Pakistan. Qualitative Research in Financial Markets, 3(2), 117-130.

Hui, E. C.-M. (2004). An empirical study of the effects of land supply and lease conditions on the housing market. Property Management, 22(2), 127-154.

Iblher, F., \& Lucius, D. I. (2003). Innovative real estate financing in Germany - A financial desert? Property Management, 21(1), 82-96.

Irumba, R. (2015). An empirical examination of the effects of land tenure on housing values in Kampala, Uganda. International Journal of Housing Markets and Analysis, 8(3), 359-374.

Ismail, A., Bujang, A. A., Jiram, W. R. A., Zarin, H. A., \& Jaafar M. N. (2015). Factor affecting the housing financing of Bumiputera in Iskandar, Malaysia. Journal of Economics, Business and Management, 3(11), 1031-1036.

Kagochi, J. M., \& Mace, L. M. (2009). The determinants of demand for single family housing in Alabama urbanized areas. International Journal of Housing Markets and Analysis, 2(2), 132-144.

Kajuth, F., Knetsch, T. A., \& Pinkwart, N. (2016). Assessing house prices in Germany: Evidence from a regional data set. Journal of European Real Estate Research, 9(3), 286-307.

Kasanga, R. K. (1995). Land tenure and regional investment prospects: The case of the tenurial systems of Northern Ghana. Property Management, 13(2), 21-31.

Kassim, S. H., Majid, M. S. A., \& Yusof, R. M. (2009). Impact of monetary policy shocks on the conventional and Islamic banks in a dual banking system: Evidence from Malaysia. Journal of Economic Cooperation and Development, 30(1), 41-58.

Khazanah Research Institute. (2015). Making housing affordable. Kuala Lumpur: Author 
Rosylin Mohd Yusof, Shazida Jan Mohd Khan, Fauziah M. Yusuf, \& Nurul Huda Abdul Majid

Bridging the Supply and Demand Gap for Affordable Home Ownership in Malaysia:The Roles of Government and Financial

Institutions

Kryvobokov, M. (2004). Urban land zoning for taxation purposes in Ukraine. Property Management, 22(3), 214-229.

Lee, C. L. (2009). Housing price volatility and its determinants. International Journal of Housing Markets and Analysis, 2(3), 293-308.

Malik, S., \& Wahid, J. (2014). Rapid urbanization: Problems and challenges for adequate housing in Pakistan. Journal of Sociology and Social Work, 2(2), 87-110.

Meera, A. K. M., \& Abdul-Razak, D. (2005). Islamic home financing through musharakah mutanaqisah and al-bay' bithaman ajil contracts: A comparative analysis. (n.p.): (n.p.)

Mohammad, S., \& Ghauri, K. (2015). Why interest-rate cannot benchmark for Islamic financial product pricing? Benchmarking: An International Journal, 22(7), 1417-1428.

Osman, M. M., Yusop, S. W. M., Shuid, S., \& Abdullah, M. F. (2017). Housing affordability index for districts in Perak. Advanced Science Letters, 23(7), 60496052.

Oyewole, M. O. (2010). Housing development finance through cooperative societies. International Journal of Housing Markets and Analysis, 3(3), 245-255.

Painter, G., \& Redfearn, C. L. (2002). The role of interest rates in influencing long run homeownership rates. Journal of Real Estate Finance and Economics, 25(2/3), 243-267.

Phang, S.-Y. (2010). Affordable homeownership policy. International Journal of Housing Markets and Analysis, 3(1), 38-52.

Phang, S.-Y., \& Helble, M. (2016). Housing policies in Singapore. Asian Development Bank Institute, Working Paper 559.

Phibbs, P.., \& Young, P. (2005). Housing assistance and non-shelter outcomes. AHURI Final Report; no.74. Melbourne: Australian Housing and Urban Research Institute.

Piazzesi, M., \& Schneider, M. (2009). Momentum traders in the housing market: Survey evidence and a search model. NBER Working Paper no. 14669, January 2009.

Poon, J., \& Garratt, D. (2012). Evaluating UK housing policies to tackle housing affordability. International Journal of Housing Markets and Analysis, 5(3), 253271.

Rowley, S. \& Ong, R. (2012). Housing affordability, housing stress and household wellbeing in Australia. AHURI Final Report; no.192. Melbourne: Australian Housing and Urban Research Institute.

Shiller, R. J. (2007). Understanding recent trends in house prices and home ownership. Cowles Foundation for Research in Economics, Discussion Paper No. 1630.

Smolo, E., \& Hassan, M. K. (2011). The potentials of mushārakah mutanāqisah for Islamic housing finance. International Journal of Islamic and Middle Eastern Finance and Management, 4(3), 237-258.

Taltavull de La Paz, P., \& White, M. (2016). The sources of house price change: Identifying liquidity shocks to the housing market. Journal of European Real Estate Research, 9(1), 98-120.

Tameme, M., \& Asutay, M. (2012). An empirical inquiry into marketing Islamic mortgages in the UK. International Journal of Bank Marketing, 30(3), 150-167. 
Udechukwu, C.E. (2008). Obstacles to individual home ownership in Nigeria. International Journal of Housing Markets and Analysis, 1(2), 182-194.

Usman, H., \& Lizam, M. (2016). Determinants of intention of using mortgage in financing home ownership in Bauchi, Nigeria. International Journal of Housing Markets and Analysis, 9(3), 320-339.

Zainal, N. R., Kaur, G., Ahmad, N. A., \& Khalili, J. M. (2012). Housing conditions and quality of life of the urban poor in Malaysia. Procedia - Social and Behavioral Sciences, 50, 827-838.

Zhu, H. (2006). The structure of housing finance markets and house prices in Asia. Bank for International Settlement, Quarterly Review, December 2006.

\section{Appendix 1}

Evaluating Government Effort in promoting homeownership:

$$
\Delta H O T_{t}=\propto_{0}+\propto_{2} \Delta H P I+\propto_{3} \Delta G D P+\propto_{4} \Delta E S U+\propto_{5} \Delta L S S
$$

Evaluating Government Effort and Total Financing in promoting homeownership:

$$
\Delta H O T_{t}=\propto_{0}+\propto_{2} \Delta H P I+\propto_{3} \Delta G D P+\propto_{4} \Delta E S U+\propto_{5} \Delta L S S+\propto_{6} \Delta H F T
$$

Evaluating Government Effort and Islamic Home Financing in promoting homeownership: $\Delta H O T_{t}=\propto_{0}+\propto_{2} \Delta H P I+\propto_{3} \Delta G D P+\propto_{4} \Delta E S U+\propto_{5} \Delta L S S+\propto_{6} \Delta H F I$

Where;

HOT $=$ Homeownership Transferred

Government Effort:

$\mathrm{ESU}=$ Existing Residential Stocks

LSS $=$ Hectares of Land Supply for Building Development

Home Financing:

HFI $=$ Islamic Home Financing Approved

HFT $=$ Total Home Financing Approved

Macroeconomic Variables:

HPI $=$ Housing Price Index

GDP $=$ Gross Domestic Products 